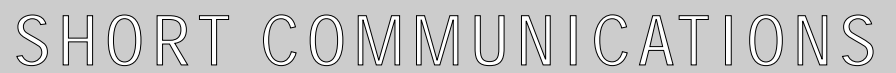

\section{Usefulness of a rapid method to cultivate sterile body fluid specimens}

\author{
Antonietta Cavallaro, Laura Squarzon \\ Microbiology and Virology Unit, Hospital of Padova, Italy
}

Key Words: Life-threatening infections; Sterile body fluids; Uro4 HB\&L automated system

Utilità di un metodo rapido per la coltura dei liquidi biologici provenienti da distretti sterili

\section{SUMMARY}

At the present, diagnosis of invasive infections is commonly based on the cultivation of pathogenic microorganisms with subsequent morphological and biochemical identification, followed by several types of antimicrobial susceptibility tests. Early identification and rapid antimicrobial susceptibility testing of microorganisms causing these invasive and life-threatening infections are high priorities in clinical microbiology laboratories. Aim of our study was to investigate whether Uro4 HB\&L automated system (Alifax S.p.A., Padova, Italy) anticipates the recovery of microorganisms from sterile body fluids other than traditional cultural methods.

\section{INTRODUCTION}

Many invasive and life-threatening infections, such as meningitis, pericarditis, peritonitis, septic arthritis and empyema are traditionally diagnosed by culturing sterile body fluids specimens coming from the sites of infections (1).

Several recent studies in the literature reported the importance of rapid detection of the causative pathogens to start a prompt and an appropriate antimicrobial treatment, especially in cases of suspected meningitis and bloodstreams infections, by using molecular diagnostic methods $(2,3,11$, 12). Anyway, microbiological cultures are currently regarded as the reference method for the identification of pathogenic bacteria (6).

The employment of a broth medium in addition to multiples solid media has long been recognized as a useful method for enhancing the recovery and reducing the time to detect fastidious microorganisms in body fluids $(6,8)$.

However, the sensivity of these cultures is very variable and depends both on the context in which the clinical samples are taken and on the pathogen involved (4).

Therefore, the necessity to obtain reliable and quick results has arosen the spreading of automated diagnostic methods in microbiology. Recently, Uro4 HB\&L system has been employed for bacte- rial screening in urine and several biological samples, with rapid outcomes $(5,7,9,10)$.

The system uses the light scattering technology to detect the growth of bacteria, providing real-time growth curves and bacterial counts $(\mathrm{cfu} / \mathrm{ml})$ and allowing the determination of the specific antimicrobial activity for each samples. In this study, we apply Uro4 HB\&L for the automation of sterile body fluids specimens analysis to improve the menagement of critical patients with life-threatening conditions.

\section{MATERIALS AND METHODS}

From January to March 2008, we evaluated 160 consecutive clinical samples coming from different divisions of Padova Hospital: 64 pleuric fluids, 80 peritoneal fluids, 15 joint fluids, and 1 pericardial fluid. All samples were seeded onto different solid media for bacteria and fungi recovery.

Plates were incubated at $37^{\circ} \mathrm{C}$ in opportune conditions: sheep blood agar was incubated 24 hours in anaerobiosis and 24 hours in aerobiosis, chocolate agar was incubated for 48 hours in presence of oxygen and $5 \% \mathrm{CO}_{2}$, while Saboureaud dextrose agar and MacConkey's agar (bioMerieux®) were incubated at $37^{\circ} \mathrm{C}$ for $48 \mathrm{~h}$ in aerobic conditions. The traditional cultivation method was cou-

\section{Corresponding author: Antonietta Cavallaro}

Via Giustiniani 2, 35100 Padova, Italy

Tel: 049 82।305। - Fax: 0498213054

E-mail: antonietta.cavallaro@sanita.padova.it 
pled with an enrichment culture in thioglycollate broth. Identifications and antimicrobial susceptibility tests were made by Vitek2 (bioMerieux ${ }^{\circledR}$ ). In parallel with this routinary flow, $500 \mu \mathrm{l}$ of each sample were seeded in a $2 \mathrm{ml}$ HB\&L broth vial, which was incubated for 6 hours in the Uro4 $\mathrm{HB} \& \mathrm{~L}$ machine at $37^{\circ} \mathrm{C}$. Growth curves were followed on the computer screen and only just positive sign appears, a Gram stain microscopy was performed to preliminary identify the infectious agent. To evaluate the ability of the Uro4 HB\&L system to support the growth of bateria, standard reference strains were used: Haemophylus influenzae (ATCC 49247), Escherichia coli (ATCC 35218 and ATCC 25922), Candida parapsilosis (ATCC 22019), Enterococcus faecalis (ATCC 51299 and ATCC 29212), Pseudomonas aeruginosa (ATCC 27853) and Staphylococcus aureus (ATCC 25923).

\section{RESULTS}

Out of 160 sterile body fluids samples analized with the reference method, $56 \%$ of them were positive for Gram negatives bacteria (Escherichia coli and Pseudomonas aeruginosa were the most represented species), while 35\% of samples were positive for Gram positives bacteria (in particular Enterococcus faecalis and Staphylococcus aureus). Anaerobic organisms, such as Veillonella spp. and Bacteroides fragilis, and fungi, such as Candida spp., were also isolated, Table 1.

Comparing reference culture method and Uro4 HB\&L system, the agreement was reached for 156 samples ( $97.5 \%$ of the totality): $45.6 \%$ of them were true negatives, $18.8 \%$ true positives, $33.1 \%$ false positives and $2.5 \%$ false negatives. Relevant mismatches between two methods were verified on false negatives: 4 positive samples were not identified by Uro4 HB\&L system. The microorganisms were one anaerobic and three Gram positives. However, all of them were ricovered by the respective thioglycollate broths, Table 1 and Table 2.
Table I. Species differently isolated with standard cultural method and Uro4 HB\&L system

\begin{tabular}{|c|c|c|}
\hline $\begin{array}{r}\text { specie } \\
\text { with } \\
\text { cultur }\end{array}$ & $\begin{array}{l}\text { No. of } \\
\text { es isolated } \\
\text { standard } \\
\text { ral method }\end{array}$ & $\begin{array}{c}\text { No. of } \\
\text { species isolated } \\
\text { with Uro4 } \\
\text { HB\&L system }\end{array}$ \\
\hline Bacteroides fragilis & I & $\mathrm{I}$ \\
\hline Candida species & $\mathrm{I}$ & 1 \\
\hline Corynebacterium striatum & $\mathrm{I}$ & 1 \\
\hline Enterobacter cloacae & $\mathrm{I}$ & $\mathrm{I}$ \\
\hline Enterococcus faecium & $\mathrm{I}$ & $\mathrm{I}$ \\
\hline Enterococcus faecalis & 4 & 3 \\
\hline Enterococcus gallinarum & $\mathrm{I}$ & $\mathrm{I}$ \\
\hline Escherichia coli & 7 & 7 \\
\hline \multicolumn{3}{|l|}{ Escherichia coli and } \\
\hline Enterobacter cloacae & I & I \\
\hline \multicolumn{3}{|l|}{ Morganella morgani and } \\
\hline Citrobacter freundii & I & I \\
\hline \multicolumn{3}{|l|}{ Morganella morgani and } \\
\hline Escherichia coli & I & $\mathrm{I}$ \\
\hline \multicolumn{3}{|l|}{ Proteus mirabilis and } \\
\hline Enterococcus faecalis & I & I \\
\hline Psaeudomonas aeruginosa & 3 & 3 \\
\hline Staphylococcus aureus & 4 & 3 \\
\hline Streptococcus constellatus & 2 & 2 \\
\hline Staphylococcus haemolyticus & $s \quad 1$ & 1 \\
\hline Streptococcus mitis & $\mathrm{I}$ & 0 \\
\hline Streptococcus pyogenes & $\mathrm{I}$ & $\mathrm{I}$ \\
\hline Veillonella spp. & $\mathrm{I}$ & 0 \\
\hline total & 34 & 30 \\
\hline
\end{tabular}

\section{CONCLUSIONS}

Making a suitable and rapid diagnosis for hospitalized patients who have an invasive infection consents to save their life in a brief time $(2,3)$. In this context, the development of instrument-based methods for rapid detection and identification of microorganisms plays a crucial role. Thanks to the progresses in automated microbiology and in molecular tests, it is now possible to intervene in time on the patient treatment $(11,12)$. Despite their different approach, both methods are very effective but the second one require a particular expertise. Between semi-automated system, Uro4

Table 2. Comparative yields of clinically significant isolates with standard cultural method and Uro4 HB\&L system

\begin{tabular}{|c|c|c|c|c|c|}
\hline specimens & $\begin{array}{c}\text { No. of } \\
\text { specimens } \\
(\%)\end{array}$ & $\begin{array}{c}\text { No. of } \\
\text { positive samples } \\
\text { by standard } \\
\text { cultural method }\end{array}$ & $\begin{array}{c}\text { No. of } \\
\text { negative samples } \\
\text { by standard } \\
\text { cultural method }\end{array}$ & $\begin{array}{c}\text { No. of } \\
\text { positive samples } \\
\text { by Uro4 HB\&L } \\
\text { system }\end{array}$ & $\begin{array}{c}\text { No. of } \\
\text { negative samples } \\
\text { by Uro4 HB\&L } \\
\text { system }\end{array}$ \\
\hline PLEF & $64(40 \%)$ & 7 & 57 & 35 & 29 \\
\hline PERF & $80(50 \%)$ & 25 & 55 & 39 & 41 \\
\hline JF & $15(9,4 \%)$ & 2 & 13 & 4 & 11 \\
\hline PERICF & $\mathrm{I}(0,6 \%)$ & 0 & $\mathrm{I}$ & 1 & 0 \\
\hline total & 160 & 34 & 126 & 79 & 81 \\
\hline
\end{tabular}

PLEF- pleural fluid; PERF- peritoneal fluid; JF- joint fluid; PERICF-pericardial fluid 
HB\&L represents a new tool to rapidly screen the presence of microorganisms in sterile body fluids specimens with the employment of an enrichment broth $(5,7,9,10)$. The system is easy to use and allows to discriminate positive samples from negatives in a very short time (only 6 hours) with an high level of reliability. In our samples, we noticed an high percentage of false positives but this trouble can be corrected with a microscopic slide smear. Therefore, Uro4HB\&L system represents an efficient instrument for prompt diagnosis and treatment of infection which can become a danger for patients in compromised conditions.

\section{BIBLIOGRAPHY}

1. Akcam FZ, Yayli G, Uskun E, et al. Evaluation of the Bactec microbial detection system for culturing miscellaneous sterile body fluids. Res Microbiol 2006; 157: 433-6

2. Bøving MK, Pedersen LN, Møller JK. Eight-plex PCR and liquid-array detection of bacterial and viral pathogens in cerebrospinal fluid from patients with suspected meningitis. J Clin Microbiol 2009; 47: 90813. Epub 2009 Feb 4

3. Chiba N, Murayama SY, Morozumi M, et al. Rapid detection of eight causative pathogens for the diagnosis of bacterial meningitis by real-time PCR. $J$ Infect Chemother 2009; 15: 92-8. Epub 2009 Apr 25
4. Fihman V, Hannouche D, Bousson V, et al. Improved diagnosis specificity in bone and joint infections using molecular techniques. J Infect 2007; 55: 510-7

5. Fontana C, Favaro M, Minelli S, et al. A novel culturing system for fluid samples._Med Sci Monit. 2009;15: 55-60

6. Isenberg DH. Clinical Microbiology Procedures Handbook. $2^{\text {nd }}$ Edition, ASM Press, Washington DC; 2007; sections 2-3-4

7. Milagro A, Moles B, Seoane A, et al. UTIscreen versus UROQUICK: two semiautomatic systems for bacteriuria detection Enferm Infecc Microbiol Clin 1999; 17: 398-400

8. Miller JM, Holmes HT, Krisher K. General principles of specimens collection and handling. In. Murray P, Baron EJ, Jorgensen JH et al (eds.), Manual of Clinical Microbiology. $8^{\text {th }}$ ed. Washington DC: ASM; 2003; 1:55-66

9. Roveta S, Marchese A, Debbia EA. Antibiotic susceptibility test directly on urine samples usingUro-Quick, a rapid automated system. J Chemoter 2006; 18: 12-9

10. Roveta S, Marchese A, Debbia EA. Evaluation of the Uro-Quick, a new rapid automated system, for the detection of well-characterized antibiotic resistant bacteria. J Chemoter 2004; 16: 107-18

11. Varani S, Stanzani M, Paolucci M, et al. Diagnosis of bloodstream infections in immunocompromised patients by real-time PCR. J Infect. 2009; 58:346-51.

12. Westh H, Lisby G, Breysse F, et al. Multiplex realtime PCR and blood culture for identification of bloodstream pathogens in patients with suspected sepsis. Clin Microbiol Infect. 2009 [Epub ahead of print] 